\title{
Interrelationship of Chlamydia trachomatis and other pathogens in the female genital tract
}

\author{
G. L. RIDGWAY AND J. D. ORIEL \\ From the Departments of Clinical Microbiology and Genito-urinary medicine, University College Hospital, \\ London
}

SUMMARY The isolation of Neisseria gonorrhoeae, Chlamydia trachomatis, Trichomonas vaginalis, and Candida albicans in the female genital tract was studied in 1323 patients attending a venereal disease clinic. Disruption of the cell monolayers used for the isolation of $C$. trachomatis was significantly associated with the presence of $T$. vaginalis; this effect was markedly reduced by the addition of vancomycin to gentamicin and amphotericin $B$ in the transport and growth media. The only significant positive association was the more frequent isolation of $C$. trachomatis in the presence of $N$. gonorrhoeae. There was a negative association between $N$. gonorrhoeae and $C$. albicans and between $T$. vaginalis and $C$. albicans, the fungus being isolated significantly less frequently when these microorganisms were present.

The female genital tract provides a satisfactory environment for many pathogenic microorganisms, and multiple infections are therefore common (Wentworth et al., 1973). In sexually transmitted diseases, the causative organisms of more than one infection may be acquired simultaneously, or one species of organism may join other species which have persisted since a previous infecting episode. The presence of multiple infections may make the interpretation of symptoms and signs relating to a particular pathogen difficult.

Bacterial interaction is a familiar phenomenon, as exemplified by the satellitism of Haemophilus influenzae around staphylococcal colonies, or the production of antibiotics and bacteriocines by microorganisms in vitro (Wickman, 1970). That bacterial interactions may occur in the genital tract has been suggested by the observations of Kraus et $a l$. (1976) on the inhibitory effect of certain bacterial species against $N$. gonorrhoeae, and it has been suggested that $C$. albicans may also be inhibitory (Hipp et al., 1974).

In the present investigation we have considered the incidence and interrelationship of four commonly isolated microorganisms, $N$. gonorrhoeae, $C$. trachomatis, $T$. vaginalis, and $C$. albicans. Specimens were collected from a group of women attending a venereal disease clinic, and statistical methods were used to seek associations between pairs of organisms.

Received for publication 28 February 1977

\section{Patients and methods}

Between January and April 1975, 1323 consecutive female patients were examined. Of these, 268 were sexual contacts of men with gonorrhoea, 485 of men with non-gonococcal urethritis, and seven of men with other sexually transmitted diseases. The remaining 563 women attended with a request for examination because of either symptoms or anxiety about possible infection.

After interview patients were examined in the lithotomy position; a Cusco speculum was used to expose the cervix. Specimens were collected from the urethra and cervix for Gram staining and culture for $N$. gonorrhoeae, from the cervix for cell culture for $C$. trachomatis, and from the vagina as a wet mount for the identification of trichomonads and yeast cells and hyphae and for culture for $T$. vaginalis and Candida spp.

\section{BACTERIOLOGY}

Chlamydia trachomatis

An endocervical swab was broken into $2 \mathrm{ml}$ transport medium and held at $4^{\circ} \mathrm{C}$ for not more than two hours. After agitation, $1 \mathrm{ml}$ of this material was used to inoculate a monolayer of McCoy cells pretreated with 5 iodo $2^{\prime}$ deoxyuridine. All media contained amphotericin B, $2.5 \mu \mathrm{g} / \mathrm{ml}$ and gentamicin, $10 \mu \mathrm{g} / \mathrm{ml}$. The preparation was centrifuged and incubated at $37^{\circ} \mathrm{C}$ for 48 hours; the cells were then fixed, stained 
with iodine, and examined microscopically for inclusions (Reeve et al., 1975).

Neisseria gonorrhoeae

Endocervical and urethral swabs were plated directly on to warm modified Thayer-Martin medium (Phillips et al., 1972) and incubated at $37^{\circ} \mathrm{C}$ in $10 \%$ carbon dioxide for 36 hours. Suspect colonies were identified by Gram stain, oxidase reaction, and specific immunofluorescence.

Trichomonas vaginalis

Vaginal specimens suspended in normal saline were examined immediately under a $1 / 6$ inch high dry objective for motile trophozoites. Specimens for culture were incubated at $37^{\circ} \mathrm{C}$ for 48 hours in Feinberg-Whittington medium and then examined microscopically as above.

Candida albicans

Swabs from the vagina were inoculated directly on to Sabouraud's medium and incubated at $37^{\circ} \mathrm{C}$ for 48 hours. The presence of $C$. albicans was confirmed by subculture into serum for germ tube identification (Mackenzie, 1962).

The isolation data were subjected to computer analysis, and the level of statistical significance was assessed by calculation of the $\mathrm{Z}$ score between the basal isolation rate of an organism alone and in combination with other organisms. The level of significance was taken as $99 \%(\mathrm{P}<0.01)$.

\section{Results (Table 1)}

CONTAMINATION OF CHLAMYDIA CULTURES In $187(14.1 \%)$ of 1323 cervical specimens examined by cell culture for $C$. trachomatis, the supernatant after incubation was cloudy and the cell monolayer so disrupted that inclusion formation could not be detected; these specimens were regarded as "contaminated' by bacterial action. It is of interest that while $40(35.1 \%)$ of 114 specimens from patients with trichomoniasis were 'contaminated', only 147 $(12.2 \%)$ of 1209 patients without trichomoniasis yielded 'contaminated' Chlamydia cultures. This $\stackrel{\text { 을 }}{\Rightarrow}$ difference is significant $(\mathbf{P}<0.001)$. There were no $\overrightarrow{\vec{F}}$ associations between 'contaminated' Chlamydia cultures and infection by $N$. gonorrhoeae or $C$. 흠 albicans.

Investigation of the 'contaminated' specimens $\widehat{\overparen{D}}$ showed that, in the majority of these, Streptococcus spp. were isolated. The subsequent addition of ${ }^{\text {s }}$ vancomycin, $10 \mu \mathrm{g} / \mathrm{ml}$, to the gentamicin and $\overrightarrow{0}$ amphotericin B already in use has led to a marked $\overrightarrow{-}$ decrease in the numbers of 'contaminated' specimens $\stackrel{\omega}{\circ}$ from women both with and without trichomoniasis. 횽

ASSOCIATION OF MICROORGANISMS

C. trachomatis was recovered from cervical speci- $\vec{O}$ mens from $151(21.1 \%)$ of 717 patients in whom noce other infecting agent was present. However, $C$. trachomatis was isolated in $75(36.6 \%)$ of 205 음 cervical specimens from women infected by $N$. $\vec{\circ}$ gonorrhoeae. This difference is significant $(\mathrm{P}<0.001)$. C. trachomatis was isolated from $30(18.8 \%)$ of 160 음 patients infected by C. albicans and from $11(22 \cdot 4 \%) \stackrel{\Phi}{\subseteq}$ of 49 women infected by $T$. vaginalis; there was thus $\vec{P}$ no significant association between $C$. trachomatis and $\stackrel{\theta}{V}$ either $C$. albicans or $T$. vaginalis.

As sole pathogen, C. albicans was recovered from $184(18.5 \%)$ of 996 patients. In the presence of $N$. gonorrhoeae, however, $C$. albicans was recovered from only $14(6.6 \%)$ of 213 patients. This negative association is significant $(\mathrm{P}<0.01)$. C. albicans was $\varrho$ present in $8(4.2 \%)$ of 192 patients infected by $T . \overrightarrow{\vec{B}}$ vaginalis. Again, this negative association is sig- $\frac{3}{3}$ nificant $(\mathrm{P}<0.01)$.

PREVALENCE OF PATHOGENS

Over one half of the population studied was infected? by one or more of the four selected pathogens. The commonest of these was $C$. trachomatis, which occurred in $23.7 \%$ of patients; $N$. gonorrhoeae was recovered from $17 \cdot 5 \%, T$. vaginalis from $7 \cdot 2 \%$, and C. albicans from $15.6 \%$ of women. The occurrence of $\stackrel{\circ}{\supset}$ multiple infections was apparent; of 1136 patients $\frac{7}{2}$ with complete pathogen information (ie, excluding 187 women with 'contaminated' cultures for $C$. N

Table 1 Interrelationship of pathogens isolated from 1323 patients

\begin{tabular}{|c|c|c|c|c|c|c|c|c|c|}
\hline \multirow[t]{2}{*}{ C. trachomatis } & \multicolumn{9}{|c|}{ Pathogens isolated } \\
\hline & None & $\begin{array}{l}\text { N. } \\
\text { gonorrhoeae }\end{array}$ & $\begin{array}{l}\text { T. } \\
\text { vaginalis }\end{array}$ & $\begin{array}{l}\text { C. } \\
\text { albicans }\end{array}$ & $\begin{array}{l}\text { N.gon }+ \\
\text { T. vag }\end{array}$ & $\begin{array}{l}\text { N. gon + } \\
\text { C. alb }\end{array}$ & $\begin{array}{l}\text { T. vag + } \\
\text { C. alb }\end{array}$ & $\begin{array}{l}\text { N. gon + } \\
\text { T. vag + } \\
\text { C. alb }\end{array}$ & Total \\
\hline \multirow{2}{*}{$\begin{array}{l}\text { Isolated } \\
\text { Not isolated } \\
\text { Specimen } \\
\text { contaminated }\end{array}$} & $\begin{array}{l}151 \\
566\end{array}$ & $\begin{array}{r}63 \\
109\end{array}$ & $\begin{array}{l}11 \\
38\end{array}$ & $\begin{array}{r}30 \\
130\end{array}$ & $\begin{array}{r}8 \\
12\end{array}$ & $\begin{array}{l}4 \\
9\end{array}$ & 2 & $\begin{array}{l}\mathbf{0} \\
\mathbf{0}\end{array}$ & $\begin{array}{l}269 \\
867\end{array}$ \\
\hline & 95 & 27 & 25 & 24 & 11 & 1 & 3 & 1 & 187 \\
\hline
\end{tabular}

N. gon $=$ Neisseria gonorrhoeae $; T$. vag $=$ Trichomonas vaginalis; $C$. alb = Candida albicans. 
Table 2 Frequency of multiple isolation of pathogens from 1136 female patients

\begin{tabular}{lcc}
\hline No. of pathogens & No. of patients & Percentage \\
\hline 0 & 566 & $49 \cdot 8$ \\
1 & 428 & $37 \cdot 7$ \\
2 & 128 & $11 \cdot 3$ \\
3 & 14 & $1 \cdot 2$ \\
Total & 1136 & 100 \\
\hline
\end{tabular}

trachomatis), $570(50 \cdot 2 \%)$ were infected with at least one pathogen, and $142(12.5 \%)$ with more than one pathogen (Table 2).

\section{Discussion}

The prevalence of $C$. trachomatis in our study group $(23.7 \%)$ was comparable with figures reported from other VD clinics in Britain and the USA (Wentworth et al., 1973; Hilton et al., 1974; Oriel et al., 1974). In comparison, $N$. gonorrhoeae was less common, occurring in $18.5 \%$ of women.

The relative difficulty of obtaining valid isolation results for $C$. trachomatis in the presence of $T$. vaginalis poses a problem for the microbiologist. If 'contamination' of specimens is an effect of toxic metabolites of $T$. vaginalis, the solution might be to include an antitrichomonal drug such as metronidazole in the transport medium; this drug has little action against $C$. trachomatis (Ridgway, 1977). On the other hand, 'contamination' may be due to the release of bacteria ingested by $T$. vaginalis; in this case, additional microbials could be added to the media to eliminate possible contaminants from this source. The combination of streptomycin and vancomycin was formerly used to reduce bacterial contamination (Gordon and Quan, 1971), and we have found a marked reduction in the numbers of 'contaminated' specimens when we used gentamicin with vancomycin, and this combination seems to us to have definite advantages.

Two combinations of pathogens were uncommon $-N$. gonorrhoeae and $C$. albicans, and $T$. vaginalis and C. albicans. Like Rothenberg et al. (1976), we were unable to show a significant association between $N$. gonorrhoeae and $T$. vaginalis, although this has been found by others (Nielsen et al., 1974). However, in the present study $N$. gonorrhoeae was significantly associated with $C$. trachomatis: infection by this organism was noted in $75(36.6 \%)$ of 205 women with gonorrhoea. In a previous study (Oriel et al., 1974) we reported that $32 \%$ of such women were infected, and Hilton et al. (1974) have recorded a group of $\mathbf{4 0}$ women with gonorrhoea, of whom 25 $(62 \%)$ were infected by $C$. trachomatis. This double infection is of importance. There is good evidence that, after the treatment of gonorrhoea, C. trachomatis often remains in the genital tract of both sexes (Oriel et al., 1976). In men, the symptoms and signs of infection persist or recur ('postgonococcal urethritis'); it is not known whether a clinical syndrome of postgonococcal chlamydial infection can be defined in women, but $C$. trachomatis has been shown to be statistically associated with clinical evidence of cervicitis (Oriel et al., 1974).

The enhancement or diminution of the isolation of one microorganism in the presence of another is due to the operation of several simultaneous factors-the direct action of one organism against another, environmental conditions which selectively favour the growth of one organism, the differential operation of host factors, and epidemiological considerations. These factors are all operative within the lower genital tract in women. In planning diagnostic microbiology for women with sexually transmitted diseases, the possibility of multiple infections must be kept in mind, and the interaction of pathogenic microorganisms should also be remembered.

We are grateful to Dr E. Joan Stokes for providing laboratory facilities and to Miss Jean Owen and Miss Lam Po Tang for technical assistance.

This work was supported by a grant from the Medical Research Council.

\section{References}

Gordon, F. B. and Quan, A. L. (1971). Isolation of Chlamydia trachomatis from the human genital tract by cell culture. Trachoma and Related Disorders, edited by R. L. Nichols, pp. 476-484. Excerpta Medica Amsterdam.

Hilton, A. L., Richmond, S. J., Milne, J. D., Hindley, F., and Clarke, S. K. R. (1974). Chlamydia A in the female genital tract. British Journal of Venereal Diseases, 50, 1-10.

Hipp, S. S., Lawton, W. D., Chen, N. C.., and Gaafar, H. A. (1974). Inhibition of Neisseria gonorrhoeae by a factor produced by Candida albicans. Applied Microbiology, 27, 192-196.

Kraus, S. J., Geller, R. C., Perkins, G. H., and Rhoden, D. L. (1976). Interference of Neisseria gonorrhoeae growth by other bacterial species. Journal of Clinical Microbiology, 4, 288-295.

Mackenzie, D. W. R. (1962). Serum tube identification of Candida albicans. Journal of Clinical Pathology, 15, 563565.

Nielsen, R., Søndergaard, J., and Ullman, S. (1974). Simultaneous occurrence of Neisseria gonorrhoeae, Candida albicans and Trichomonas vaginalis. Acta Dermatovenereologica, 54, 413-415.

Oriel, J. D., Powis, P. A., Reeve, P., Miller, A., and Nicol, C. S. (1974). Chlamydial infections of the cervix. British Journal of Venereal Diseases, 50, 11-16.

Oriel, J. D., Ridgway, G. L., Reeve, P., Beckingham, 
D. C., and Owen, J. (1976). The lack of effect of ampicillin plus probenecid given for genital infections with Neisseria gonorrhoeae on associated infections with Chlamydia trachomatis. Journal of Infectious Diseases, 133, 568-571.

Phillips, I., Humphrey, D., Middleton, A., and Nicol, C. S. (1972). Diagnosis of gonorrhoea by culture on a selective medium containing vancomycin, colistin, nystatin and trimethoprim (VCNT). A comparison with Gram-staining and immunofluorescence. British Journal of Venereal Diseases, 48, 287-292.

Reeve, P., Owen, J., and Oriel, J. D. (1975). Laboratory procedures for the isolation of Chlamydia trachomatis from the human genital tract. Journal of Clinical Pathology, 28, 910-914.
Ridgway, G. L. (1977). Unpublished data.

Rothenberg, R. B., Simon, R., Chipperfield, E., and Catterall, R. D. (1976). Efficacy of selected diagnostic tests for sexually transmitted diseases. Journal of the American Medical Association, 235, 49-51.

Wentworth, B. B., Bonin, P., Holmes, K. K., Gutman, L., क Wiesner, P., and Alexander, E. R. (1973). Isolation of $\vec{\nabla}$ viruses, bacteria and other organisms from venereal $\propto$ disease clinic patients: methodology and problems $\stackrel{\infty}{\%}$ associated with multiple isolations. Health Laboratory $\vec{O}$ Science, 10, 75-81.

Wickman, K. (1970). Studies of bacterial interference in $\overrightarrow{\vec{\omega}}$ experimentally produced burns in guinea pigs. Acta $\bigcirc$ Pathologica Microbiologica Scandinavica, 78B, 15-28. 